\title{
TRADITIONAL LAND USE B Y THE ASHÁNINKA PEOPLE OF WESTERN AMAZONIA
}

\author{
Ciro Abbud Righi ${ }^{1}$, Víctor Alan Ríos Gálvez ${ }^{1}$
}

${ }^{1}$ Escola Superior de Agricultura Luiz de Queiroz - ESALQ/USP. E-mail: ciro@usp.br; victor.galvez@usp.br

\begin{abstract}
The depreciation of the traditional production systems and consequent cultural decharacterization of indigenous societies with the standardization of agriculture make urgent to understand their land use systems. The information collected has the potential to lead for more sustainable land-usesystems without imposing technological packages. The objective of the present work was to document the production systems and territorial use practiced by the Asháninka people in the Peruvian Amazon. Two agricultural systems are practiced: slash-and-burn and sandbank- seasonal cultivation along the rivers. The slash-and-burn agriculture is performed on small plots of forest land mainly in secondary regeneration (purma - Asháninka language) - easiest management. The fallow period is short (5 years) which may be leading to soil impoverishment - necessary studies of nutrient cycling to evaluate the impact. There is a need for studies to improve traditional farming systems considering not only the potential gains in productivity, but also the maintenance of their cultural identity.
\end{abstract}

Keywords: Slash-and-burn, traditional farming systems, indigenous people, territorial use

\section{USO TRADICIONAL DA TERRA PELO POVO ASHÁNINKA DA AMAZÔNIA OCIDENTAL}

\section{RESUMO}

A depreciação dos sistemas de produção tradicionais e a consequente desvalorização cultural das sociedades indígenas com a padronização da agricultura tornam urgente a compreensão de seus sistemas de uso da terra. A informação coletada tem potencial para desenvolver sistemas de uso da terra mais sustentáveis sem impor pacotes tecnológicos. O objetivo do presente trabalho foi documentar os sistemas de produção e uso territorial praticados pelo povo Asháninka na Amazônia peruana. Dois sistemas agrícolas são praticados: de derruba-e-queima e de vazante: cultivo estacional ao longo dos rios. A agricultura de derruba-e-queima é realizada em pequenas parcelas de florestas, principalmente em 
regeneração secundária (purma - na língua Asháninka) - manejo mais fácil. O período de pousio é curto (5 anos), o que pode estar levando ao empobrecimento do solo - são necessários estudos de ciclagem de nutrientes para avaliar o impacto. Existe necessidade de estudos para melhorar os sistemas agrícolas tradicionais considerando não só os potenciais ganhos de produtividade, mas também a manutenção de sua identidade cultural.

Palavras-chave: Derruba-e-queima, sistema tradicional de cultivo, povos indígenas, uso territorial

\section{INTRODUCTION}

Peru is a country of exceptional diversity. It is the fourth most biodiverse country in the world, and is ninth regarding endemic areas (CORNEJO ARANA \& MATEO, 2006). Peru is also home of 70\% of the global biodiversity, which is principally located within the Amazon region. The Amazon biome has a total area of $7.8 \times 10^{6} \mathrm{~km}^{2}$, shared between nine Latin American countries: Brazil (64.3\%), Peru (10.1\%), Colombia (6.2\%), Bolivia (6.2\%), Venezuela (5.8\%), Guyana (2.8\%), Suriname (2.1\%), Ecuador (1.5\%), and French Guiana (1.1\%); as a consequence, it is a territory of enormous socioenvironmental diversity. Thirty-three million people, divided between 385 indigenous peoples, live within the Amazon biome. About 45\% of the land area of Amazonia has been allocated to a combination of 610 protected natural areas and 2344 indigenous territories (CORNEJO ARANA \& MATEO, 2006).

According to White et al. (2005), $60 \%$ of the national territory of Peru $\left(782.9 \times 10^{3} \mathrm{~km}^{2}\right)$ is located within the Amazon biome. The Peruvian Amazon is markedly different and isolated from the rest of the country. To the west lies the Andes Range, within which the sources of most of the rivers of Amazonia and of the coastal regions of Peru along the Pacific Ocean are located. The climate of the Peruvian Amazon is hot and humid (annual rainfall from $1100 \mathrm{~mm}$ to $5000 \mathrm{~mm}$ ). The high mountains of the Andes make access into the highlands (altitudes of up to 2000m) and lowlands (altitudes down to 200m) of Amazonia difficult. Despite this, around 2.2 million people live in the Peruvian Amazon, accounting for $9 \%$ of the population of the country. The region accommodates 65 indigenous people, corresponding to 12 linguistic families; these are factors which make Peru one of the most culturally diverse countries of Latin America. Among the groups of indigenous peoples of Peru, 17 live in the zones where Peru has its borders with Brazil, Bolivia, Ecuador, and Colombia and are constantly crossing and recrossing the frontiers (ICAA, 2015). 
The Region of Ucayali in Peru contains the watersheds of several of the principal tributaries of the Amazon River, including the Purus, Ucayali, and Aguaytía rivers. Within this region are found the territories of the Cashinahua, Sharanahua, Mastanahua, Shaminahua, Culina Madija, Amahuaca, Asháninka, Yines, Shipibo Conibo, Cashibo Cacataibo people, and many others. The high part of the basin of the Purus River is the refuge of some of the last isolated indigenous Amerindians of Peru, known as the Mashco Piro (PITMAN et al., 2013).

The agricultural system adopted by most indigenous people around the world is the traditional technique of slash-and-burn, being widely used by various indigenous peoples in western Amazonia. There are many different names for these systems of nomadic cultivation adopted in different countries. These names include Swidden (England), Rai (Sweden), Coivara, Milpa, Conuco, Roça, and Chaco (Latin America), Shamba and Chitemene (Africa), Jhum (India), Kaingin (the Philippines), Ladang (Indonesia and Malaysia), and Chacra (indigenous people of Peru) (PEDROSO JR. et al., 2008).

Conklin (1957) defines slash-and-burn as a system of agriculture in which clearings are opened and cultivated for periods of time which are shorter than the fallow periods. Given a sufficiently long fallow period, the return of the secondary vegetation during the fallow period to the area cleared for cultivation ensures the recovery of the fertility of the soil, and stable agricultural production. Slash-andburn systems are recognized as important, through the extent of their pantropical use (LANLY, 1982), their maintenance of native biodiversity (LAWRENCE et al., 2007), although at reduced levels, and for their agrobiodiversity (PERONI, 1999), as reflected in the number of varieties of crops. Studies of slashand-burn systems in the Philippines and Thailand found more than 90 varieties of rice (PADOCH et al., 1985), while in Brazil the cultivation of approximately 50 varieties of cassava has been identified (PERONI, 1999).

Despite the enormous increases achieved in the productivity of large-scale agriculture, recent assessments have shown that this form of agriculture is incapable of eliminating world hunger. Further, the practice of large-scale agriculture exposes the most vulnerable segments of the world population to price fluctuations, and encourages the adoption of poorly equilibrated diets of low diversity (VIRA et al., 2015). On the other hand, traditional systems of agriculture provide alimentary subsistence to hundreds of millions of people around the world (LANLY, 1982; ATTIWILL, 1994; BRADY, 1996; CAIRNS, 2015). It has been estimated that globally, slash-and-burn agriculture is practiced across $410 \times 10^{6}$ ha of forest land, corresponding to approximately $21 \%$ of the total area covered by the tropical forests of the world. Chao (2012) has estimated that of the order of $20 \%$ of the population of the world, or 1.6 billion 252 
people, is dependent upon the forests in some way for their survival (a more extended discussion about this topic can be found in the work of Newton et al. (2016)). The uncertainty in this figure is large, but the importance of the forests cannot be doubted.

Slash-and-burn systems of agriculture have been the target of various criticisms and governments have enacted policies aimed at reducing their usage (VAN VLIET et al., 2012). However, their persistence through history until the present day in essentially all regions of the world is an indication of a need for greater understanding of the interactions between human beings and the rest of nature. The collection of information on traditional systems of cultivation is important for two reasons: firstly, it is a way to ensure that the ecological knowledge embedded within these systems is not completely lost. Secondly, in the drive for the development of more sustainable systems of agriculture, slash-and-burn systems merit attention for their longevity. The collection of information about the cultivation systems adopted by the indigenous farmers of Amazonia, together with their lifestyles and interactions with nature is still in its early stages. For the present work, data were collected on the use of the space of one village of the Asháninka people located in the Region of Ucayali in Peru, and obtained a description of the cultivation methods they employ.

\section{MATERIALS AND METHODS}

\section{The Asháninka People - "Warrior Men"}

According to Mayor \& Bodmer (2009), artifacts (bronze tools and weapons, particularly axes) found in the Amazon forest indicate the presence of Asháninka Amerindians in the Peruvian Amazon long before the appearance of the Incan Empire. Around the year 1725, Dominican and Franciscan friars, acting under orders from the Spanish Court, evangelized the Asháninka. These missionaries came from the Monastery of Ocopa in the Mantaro Valley, Junín Region, Peru. The Amazon Rubber Boom, which affected the whole of the Amazon Basin, led to the establishment of a slave trade in indigenous Amerindians, specifically of women and children, which continued until the 1950s. It was only in 1974, when the government of Peru passed the Native Communities Law, that the indigenous people had their land secured.

The period from 1986 to 1996 saw intense social conflict in Peru, between governmental forces and the Sendero Luminoso (Shining Light) and Túpac Amaru revolutionary movements. It has been estimated that during this epoch some 10,000 Asháninka were forcibly displaced from their lands, and 
between 30 and 40 Asháninka villages disappeared (MAYOR \& BODMER, 2009). According to the Commission of Truth and Reconciliation (Comisión de Verdad y Reconciliación - CVR), created by the Peruvian government in 2001, of all the indigenous peoples of Peru, the Asháninka were the most ravaged by the armed conflict. The ensuing enormous territorial displacements of hundreds of Asháninka families have had a great impact on the population dynamics of their society with members joining (or forced to join) opposite sides.

Over the years, the Asháninka have been referred to by a variety of names in the ethnographic literature, including Kampa, Camba, Thampa, Komparira, Anti, Chuncho, and Chascoso. Cultural linguistics identifies the Asháninka as belonging to the sub-Andean or pre-Andean Arawak family. Four related members of this Arawakan language group are Yanesha, Nomatsiguenga, Matsiguenga, and Piro, though there are notable differences between the languages (SORIA \& CASANTO, 2002).

According to a recent census (INEI, 2015), the Asháninka are the most numerous $(51,063)$ of the indigenous people of the Amazonian region of Peru - 22\% of the indigenous population. The Asháninka are found distributed among 359 villages located across the different states of the region. One specific area is within the state of Ucayali, where the Asháninka Amerindians are found concentrated in the basin of the River Purus which is formed from the confluence of the rivers Curuja and Cujar. The mouth of the River Purus is located in front of the Ilha do Camaleão (Chameleon Island), Amazon State Brazil, where it discharges into the Solimões River - downstream of Codajas Island (ZEE, 2005).

The territory occupied by the Asháninka extends over an enormous region from the eastern foothills of the central Andes in Peru into the state of Acre, Brazil. In Acre, the Asháninka are found in some small villages located along the Breu, Amônia, and Arara rivers, which are tributaries of the Envira and Juruá rivers. Their population in Brazil is estimated to be only 689 individuals. It is highly probable that the presence of these Asháninka in Brazil is due to the actions of the plantation owners during the period of the Amazon Rubber Boom, who brought them from the Gran Pajonal region of Junín, Peru. A further influx may have resulted from the armed conflict between the government of Peru and a number of revolutionary movements, which began in the early 1980s. However, some sources have suggested that members of the Asháninka people have been present in Brazilian territory since the end of the seventeenth or beginning of the eighteenth century, in an area principally inhabited by Pano Amerindians (KITAKA, 1991; ACRE, 2010) confirming that Asháninka people are migratory farmers (nomads), hunters, fishermen, and gatherers. 


\section{Study Area Characterization}

This study was performed in the State of Ucayali, Peru. More specifically, the Asháninka village of Pankirentsy, which is located in the province of Purus, was visited. This village is within the Peruvian Amazon, close to the border with the State of Acre, Brazil, and is situated on the banks of the Purus River. Data were collected from this indigenous community during a sequence of visits from August 2014 to January 2015 (Figure 1). One factor that greatly contributed to the acceptance of the research team and consequently to the success of the study was the manner in which the leader of the village accompanied the visits. This leader also provided invaluable assistance during the interviews that were conducted with the village members, many of whom could only communicate in their native language of Asháninka. The leader acted as interpreter between the dialect or local indigenous language used by the Amerindians and Spanish.

The State of Ucayali has a land area of $102000 \mathrm{~km}^{2}$, representing $8 \%$ of the national territory of Peru. This state extends from the central zone of Peru to its eastern border with Brazil (State of Acre). The state capital is Pucallpa, which lies $489 \mathrm{~km}$ northeast of the capital of Peru, Lima. Annual precipitation varies from 1600 to $2750 \mathrm{~mm}$, while the average mean temperature is $24.5^{\circ} \mathrm{C}$. According to climate classification scheme of Köppen, the local climate is of type Am, tropical monsoon, meaning that it is hot with abundant rainfall and a short dry season. Other features of the climate are occasional periods of exceptional coldness ("friagens") and heat ("veranicos"). During a "friagem", which lasts from two to six days and is caused by the arrival of a mass of cold air from the extreme south of Latin America, the temperature can fall by as much as $16^{\circ} \mathrm{C}$. In the midst of a "veranico", the maximum temperature climbs to $40^{\circ} \mathrm{C}$ (INRENA, 2005).

Topographically the State of Ucayali is characterized by the presence of innumerable hills, with declivities ranging from low to high. The vegetation is primarily mixed forest, containing trees of broadleaf, deciduous, and evergreen species, together with shrubs and herbaceous plants. This abundance of plant life is put to a variety of uses by the local riverside dwellers and indigenous Amerindians, so that trees and plants provide medicines, timber, and materials for handmade crafts, as well as food. 


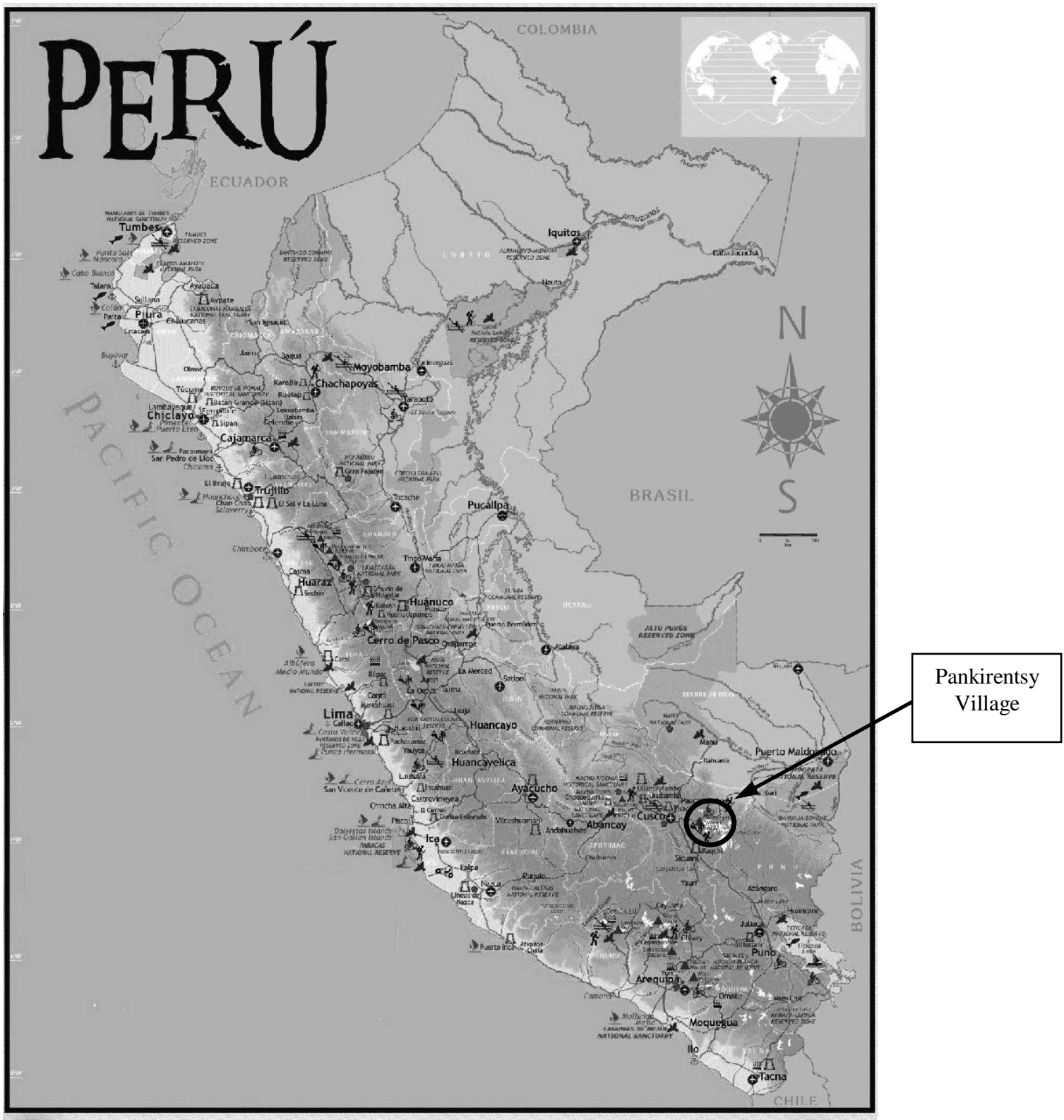

Figure 1. Approximated location of the Pankirentsy village from the Asháninka tribe at the Amazon area in Ucayali - Peru. 


\section{Methodology}

In order to determine and evaluate the systems of traditional agriculture employed by the local Amerindians and their use of the land, the Diagnosis and Design (D\&D) methodology promulgated by

the World Agroforestry Centre - ICRAF (BENIEST et al., 1993) was adopted - a short description of this is given a little further below. In this study only the diagnosis part of the D\&D methodology was performed describing the agricultural systems adopted. Certain adaptations were made to translate the methodology to the situation of the Amerindians of Amazonia, which led to the development of a series of tools that are described in the following sections.

The village of Pankirentsy sits on the banks of the Purus River, and can be reached by small boat in about one hour from the nearby town of Puerto Esperanza in Peru, or in about six hours starting from Santa Rosa do Purus in Brazil. Ten out of the twenty families who live in Pankirentsy were interviewed. These interviews took the form of informal conversations with the inhabitants and followed a pre-defined script, which targeted the collection of qualitative and quantitative information about the systems of agriculture employed, and the relationships of the villagers with their environment and other settlements. In most cases, the interviews were conducted with the head of each family, $60 \%$ of whom were men. In addition to the interviews, all of the plots cultivated by each of these families were visited. These cultivation plot visits were always accompanied by a village member, and were generally made with the owner of the plot. Photographs of the plots were taken, and the species under cultivation were identified and recorded.

\section{Diagrams and Maps}

The diagrams and maps prepared from the data collected during the field visits illustrate the temporal and spatial dependence of a variety of biophysical and socioeconomic parameters. All the diagrams and maps were created with the participation of members of the indigenous families (parents, children, grandparents, aunts, and uncles), who drew their own maps on card with wax crayons. The maps helped to identify the important attributes of the area around the village, and to provide an understanding of the interactions and relationships that govern the land-use, both spatially and temporally. A few selected drawings, considered the most illustrative, are reproduced in this article. Temporal records included the changing pattern of land use over time and the seasonal agricultural calendar. 
The Farm Layout Map provides a general panorama of the village and land use. These drawings show the locations and approximate sizes of items such as tracks, plots, streams, the craft workshop, and the homes of the families, as well as the distances and directions to other settlements in the area where markets, schools, and health posts were situated. The Gender Resources Map, which was combined in the same draw of the Farm Layout Map, presents the locations of the daily activities of each member of the family, and marks their responsibilities and tasks. The Backyard Map was drawn by the head of the family (father or mother); the objective here was to provide a description of the plants grown around the family home (kitchen garden), which are quite distinct from the crops raised in the cleared plots. To complete the mapping of the Agroecological System, the three previously mentioned maps were superimposed, and supplemented with information on non-seasonal activities occurring anywhere within the radius of action of the visited families. These Agroecological System diagrams provide a general description of the farming system, and incorporate the fluxes and quantities of materials. The intention was to capture the full range of activities undertaken by the indigenous families, and build an in situ comprehension of the agricultural practices employed.

Temporal data on the historical evolution of the land use were collected from the oldest members of the indigenous families and the village elders $(a p u)$ in the form of diagrams filled with drawings to indicate the area of land under a particular use with one axis as time. These graphical representations were summarized by generating a Historical Land Use Transect, which showed the changes recorded in the memories of these individuals. Information gathered on the associated annual sequence of agricultural activities was used to construct a Farming Calendar.

\section{RESULTS}

\section{Demographics}

The arrival of individuals of the Asháninka people in the basin of the Purus River is recent, and dates from 1997, when some 50 families migrated into the area from the province of Satipo, Peru. Satipo is located in the State of Junín, and the families came from a part of the Peruvian Amazon with an altitude of approximately $1200 \mathrm{~m}$. The migration into the Purus Region was the result of an agreement with the local authorities of the region, who wished to encourage settlement of the area. Of the Asháninka contacted in the Purus Region, $43 \%$ were less than 15 years old, while the remainder were adults with ages between 20 and 50 years. There was a notable absence in this group of individuals with ages in 
excess of 55 years. According to local reports, the indigenous population in the Purus Region is decreasing due to a significant migration of Amerindians from this region of Peru into Brazil, attracted by various social programmes offered through the Brazilian government. Assistance is available through the Bolsa Família and Brasil Carinhoso schemes, as well as pensions and other subsidies, none of which exist in Peru. The result of the migration is the indigenous depopulation of the Purus Region and the abandonment of their villages in Peru. The indigenous families cross the frontier into Brazilian territory, arriving in the area under the jurisdiction of the municipality of Santa Rosa do Purus in the State of Acre, where they set up a village, which is then registered and accordingly recognized by the Brazilian National Foundation for Amerindians (FUNAI) and the municipality.

As a territory, the Purus Region is completely isolated from the rest of Peru, and there is little presence of the Peruvian government in the area, which is considered to be in a situation of extreme poverty. There are no health clinics in the region, so that the Peruvian Amerindians make use of the services offered through the nearest Indigenous Health Centre in Brazil, which is located in Santa Rosa do Purus. Among the commonly encountered health problems, two deserve highlighting due to their frequency: parasites and anaemia. Access to formal education is limited, in general, Asháninka children only receive elementary education, and there are individuals who have never passed through any sort of formal schooling.

The indigenous families of the Asháninka live in cabins constructed from a wooden frame covered with palm leaves (Attalea spp.); these palms are locally referred to as shebón and shapaja. In addition to their cabin in the village, each family possesses a second dwelling (tarima) within the forest, where they are accustomed to reside while they are working in the clearings or hunting. Their houses and agricultural plots have to be authorized by the head of the village, who is elected every two years.

\section{Slash-and-burn Agriculture}

The majority of the plots selected for cultivation are located at the back of the village and along the banks of the Purus River. During the summer (dry season), each Asháninka family will walk $4 \mathrm{~km}$ or more along tracks through the forest, which takes 2 to 3 hours to arrive at their plots. In the wet season, walking along these tracks becomes difficult. Materials and agricultural produce are carried in baskets made from palm leaves (shapaja and shebón.)

During the period from April to May, an Asháninka family generally scouts for areas of primary forest (monte alto) and secondary forest (purma) to clear and prepare as plots for agriculture. The felling 
of these two types of vegetation is initiated in the months of May (primary forest - monte alto) and June (principally forest in secondary regeneration - purma.) Felling is followed in June by the second phase, known as picacheo, in which the trees are cut into smaller pieces, branches and trunks and this facilitates the drying of the vegetable material. The time required to dry the cut down vegetation depends on its type: for primary forest about one month is sufficient, while for secondary forest the period is a maximum of 15 days. Burning commences in July and continues into August (these are the two hottest months of the year), and is normally performed as a team effort between the families of the village. After the first rains, which occur from September onwards, the planting of the crops commences. Harvesting occurs at different times throughout the year, depending on the period required for each crop to reach maturity. The first crops planted after the clearing of a plot by burning are cassava, corn, and rice, which are harvested one year and/or 5 to 6 months later. Cultivation of banana, which is a permanent crop with the first fruit available in one year, starts after the planting of cassava, corn, and rice. Planting of the crops does not follow any precise spatial pattern, and every plot is operated in a form of intercropping. After opening, a cleared plot remains in continuous production for a period of four or five years, after which it is left fallow.

The areas of the cleared plots are highly variable, ranging from as small as $50 \mathrm{~m}^{2}$ up to 2 ha. Of the families interviewed, five possessed only one plot, two families had three plots, another two possessed four plots, with only one family owning five plots. It is noteworthy that the plots owned by this latter family had larger dimensions. Of the 24 plots owned by these 10 families, all were abandoned after the four or five years of cultivation, and rested for approximately five years. During this fallow period regeneration of the native vegetation occurred. Subsequently, the plots were again cleared and returned to cultivation.

\section{Sandbank Agriculture}

Between April and September, the levels of the rivers of the Peruvian Amazon fall. This period is known as the summer or dry period of the rivers. Along the Purus River, large beaches appear, and areas of highly fertile alluvial soil are exposed. The fertility derives from the deposition of organic matter along the edges of the watercourse during the wet season. The local Amerindians take advantage of this fertile land to practice floodplain agriculture, also known as sandbank or beach agriculture, in which crop species with a short to medium vegetative cycle are raised. Crops are planted on the exposed land, and must be harvested before the next flooding of the river; the prime example of a floodplain crop is 
watermelon (Citrullus vulgaris Schrad.). The great advantage of sandbank agriculture is the ease of management of the cultivation. Little work is required, for as the river recedes it exposes an area of relatively clean soil. As the planting fields are located along the river, the Amerindians can easily reach

them by canoe. Factors which determine the success or otherwise of agriculture carried out on exposed banks within in a river are the size of the banks, their proximity to the village (careful control and vigilance are necessities), and the availability of suitable saved seeds.

\section{Agroecological Diagram}

The intent of the agroecological system diagram is to capture an overview of the full range of activities pursued by the members of the Asháninka families, both within and outside the plots they cultivate. In addition, the diagram can provide an understanding of the relationships between the activities undertaken by the villagers, and the availability and utilization of local natural resources. With the agroecological diagrams of the families of the Pankirentsy's village, it was possible to discern and interrelate the activities performed in the areas under the direct influence of the family members. For food, the majority of the indigenous villagers cultivate cassava (kaniri - Manihot esculenta) (sweet and bitter, the bitter form has higher levels of cyanide), corn (shinki - Zea mays), banana (parianti - Musa spp.) (varieties: plantain, common, seda, apple, capirona, and moquisho), cocoa (Kemito- Theobroma cacau), and sweet potato (koriti - Ipomoea batatas). There are some other crops, but in terms of volume produced, these are the most important. Cassava is the predominant crop in the cleared plots, and forms the staple in the diet of the Asháninka. Cassava is also the basis of a mildly alcoholic traditional drink consumed during social occasions. Known as Matsato in Peru and as Caiçuma in Brazil, this drink is prepared exclusively by the women of the village, through the fermentation of cooked cassava mixed with sweet potato.

Some rare and wild plant species are also cultivated, but not always in the cleared plots. Domestication has been applied, principally to certain Solanaceae and some Monocotyledons, such as Zingiberaceae (gingers) and Cannaceae (cannas), the rhizomes of the latter are consumed for they are rich in starch. Small scale cultivation of fruit bearing and medicinal plants occurs in the kitchen gardens around the dwellings of the villagers. These gardens are tended by the women, with the produce from the plants being destined for home consumption.

The subsistence of the Asháninka Amerindians comes not only from agriculture, but is also based upon the gathering of tropical fruits from the forest, examples include abiu (Pouteria caimito (Ruiz \& 
Pav.) Radlk.), açaí (Euterpe oleracea Mart.), moriche palm (Mauritia flexuosa Mart.), peach palm (Bactris gasipaes Kunth.), and sapodilla (Manilkara zapota (L.) P. Royen). The fruits available vary according to the time of the year.

Hunting is practiced by the men of the village, with firearms. The men will typically stay in the forest during the night, hiding close to fructiferous trees, whose fruits attract wild animals. In identifying the hunted animals, we give first the common name, followed in brackets by the name in the indigenous language and the scientific name. Favoured prey are deer (Manro - Mazama spp.), paca (Samani - Agouti paca), alligator (Kusaniri- Caiman spp.), monkey (Osheto - Ateles belzebuth), cotia (Sharoni Dasyprocta spp.), tortoise (Konoya -Testudo sp.), tapir (Kemary - Tapirus terrestres), peccary (Queixaa -Tayassu pecari), capybara (Obeto - Hydrochoerus hydrochaeris), and northern helmeted curassow (Tsamiri -Pauxi pauxi).

Fishing is another activity of importance to the Asháninka Amerindians, and fish represent a significant part of their diet. Compared to hunting, fishing is more accessible and requires less effort. It is however heavily dependent upon the time of the year, the water level, which varies greatly between flooding and draining, and also according to the formation of lakes close to the villages. Fishing is performed as a collective activity, mainly in the summer (dry season) in small, slow flowing rivers, and makes use of an icthyotoxin derived from the titirichi plant.

The rearing of livestock is not a common activity among Amerindian peoples. A few head of cattle and some chickens are sometimes encountered, and are raised for both local consumption and for sale.

The normal division of responsibilities within a family is that agriculture and hunting are assigned to the father and older children. The wife, in addition to caring for the house and younger children, also participates in the collection of fruits, the raising of poultry, and fishing, in addition she tends the kitchen garden. There are single mothers within indigenous communities, and they will be found working in the fields, performing the same activities as men.

The kitchen gardens of each family are located close to the dwelling, and have an area between 100 and $200 \mathrm{~m}^{2}$. Various fruits are planted in these gardens, common examples include cashew (Anacardium occidental L.), cocona (Solanum sessiliflorum Dunal), breadfruit (Artocarpus altilis (Parkinson) Fosberg), peach palm, and lemon (Citrus limon L.). Medicinal plants and herbs such as common mallow (Malva sylvestris L.), purging nut (Jatropha cursas L.), and lemon verbena (Aloysia 
citriodora Palàu) are also present in these gardens, alongside others used as seasonings, examples are Mexican coriander (Eryngium foetidum L.) and chili peppers (Capsicum sp.).

\section{Production}

Cassava is the staple in the diet of the Amerindians of Pankirentsy. The area within the cultivation plot given over to cassava varies, and is linked to the size of the family and the work necessary for the opening of the plot. Substantial areas within the cleared plots are also employed for the production of cocoa (16\%), followed by banana (14.5\%) and rice (13\%). The greater part of the production is destined for family consumption. Any excess to these domestic requirements is normally sold through the small market in Puerto Esperanza (Purus, Peru), though when the opportunity arises, the Amerindians will take produce to the town of Santa Rosa de Purus (Acre, Brazil). Despite the greater distance to Santa Rosa de Purus, the higher prices for which fresh produce can be sold in this town are considered very attractive.

Looking at the total area of the village and its associated surroundings, only a small part, just 12.9 ha (about $0.3 \%$ ) is utilized for the production of food. Cultivated plots of small size, around 1.0 to 0.5 ha, are the most common. Two people working together can sow an area of this size in one week, without calling upon the assistance of other people. Larger tasks, such as the initial opening of a clearing for cultivation, are though frequently tackled by the joint effort of people (minga) from a small group of families.

\section{Historical Land Use Transect}

With the Historical Land Use Transect it was possible to reveal the historical evolution of access to natural resources and changes in land use perceived by the Asháninka of Pankirentsy village. The Asháninka Amerindians arrived in the low Purus region of Peru in 1997, almost 20 years before the data for the present study were collected. The reports given by the older members of the community indicate that in the first years after they settled in the region there was a greater abundance of native flora and fauna within their territory. The most obvious losses in the flora have been of tree species of high economic value, such as mahogany (Swietenia macrophylla King,) and Spanish cedar (Cedrela odorata L.). When the Asháninka Amerindians arrived, they were quick to take advantage of these natural resources, by participating in the illegal commercialization and sale of timber from the local primary forests. Currently, the only remaining woodlands containing primary forest species are located close to the Santa Rosa do Purus River, in the territory marking the frontier between Peru and Brazil. 
The first crops raised in the lands occupied by the Asháninka were cassava and banana. Other crops, including pineapple, papaya, and corn, were subsequently introduced. In the first years following the establishment of Pankirentsy, fish were in high abundance in the rivers and streams close to village. However, fish stocks have been steadily declining, due to overfishing and the growing indigenous populations along the high and middle reaches of the Purus River, who depend upon fishing for their food.

Hunting is widely pursued by Amerindians, and is the source of meat necessary to their diet. There are also economic benefits to the families, through the sale of the meat. However, over time, hunting has become increasingly difficult due to a growing scarcity of wild animals, such as deer, tapir, capybara, and paca. The natural habitat of these animals is primary forest, which is being progressively lost from around the village, so that the nearest area of primary forest suitable for hunting is at least an one-day walk through the forest from the village.

\section{DISCUSSION}

Slash-and-burn agriculture is probably the oldest system of cultivation in the world (NYE \& GREENLAND, 1960) and has been practiced since the Neolithic Age, when groups of humans were replacing the nomadic hunter-gatherer lifestyle by sedentary cultures, based upon farming and grazing (HARRIS, 1972; IVERSEN, 1956). Historically, shifting cultivation has been viewed negatively, due to its contributions to many forms of environmental degradation, including loss of biodiversity and biomass from forests (VAN VLIET et al., 2012). This perception has encouraged countries to propose national governmental policies to control slash-and-burn practices, and to enforce substantial reductions in the areas where shifting cultivation is permitted. The basic characteristics of shifting cultivation causes primary forest to be transformed into forest patches, which are continuously at a secondary stage of succession, with necessarily a lower number of species. However, shifting cultivation is by far the agricultural system that is best able to maintain biodiversity (LAWRENCE et al., 2007), with the constant regeneration of the secondary forest acting as an important carbon sink (MUKUL et al., 2016). As pointed out by Van Vliet et al. (2012), shifting cultivation still remains important in many areas, especially where farmers do not have access to markets and where agricultural intensification is not viable. A further positive feature of shifting cultivation is the preservation of the multi-functionality of the land.

The observations made during our visits to Pankirentsy revealed that the Asháninka Amerindians prefer to utilize the areas of secondary forest according to a ten-year cycle, five years of production, 
followed by five years of fallow. It has been well documented that such short cycles invariably lead to soil impoverishment (ANDREAE, 1980). The local preference for a short cycle may be traced to the ease of use of the existing plots in comparison to opening new areas of much larger size in the forest. Lawrence et al. (2007), in their studies carried out in Indonesia, have documented the existence of a very strong relationship between soil fertility and the average basal area, with levels of $\mathrm{Mg}$ and $\mathrm{Ca}$ increasing in direct proportion to the average basal area. Based upon these and other observations, the maintenance of areas under fallow conditions for only a short period of time (five years) will not provide the time necessary for the growth of the trees to a basal area sufficient for recovery of the soil.

The village population consumes the greater part of the agricultural produce from Pankirentsy, the difficulties associated with transporting crops to the nearest markets mitigate against increasing production for possible commercial gain. Although more intensive use of the land could increase the incomes of the local farmers, this needs to be weighed against a number of likely negative effects on the community and the environment. The introduction of more intensive land use practices would result in a deterioration of social connections and transformations in the largely symbiotic relations between humans and nature that are customarily linked to traditional systems of agriculture. A transition from shifting cultivation to a more intensive form of agricultural practice would undoubtedly lead to permanent deforestation with a consequent loss of biodiversity and soil fertility (VAN VLIET et al., 2012). The current slash-and-burn system operated by the Asháninka has led to a decrease in species richness compared to the original primary forest. However, neither Lawrence et al. (2007) nor Gazell et al. (2012) found any relationship between species richness and nutrient stocks or litter fall. The effects of the practices followed by the Asháninka on these key fertility parameters require investigation through future studies.

According to Vinceti et al. (2013), forest and tree-based agricultural systems, also known as agroforestry systems, are capable of providing a more diverse and better balanced diet to indigenous communities. Other advantages of agroforestry systems are their ability to supply fuelwood for cooking, and to provide ecosystem services (FAO, 2011) through the longevity of the trees and the permanent cover and protection of the soil (RIGHI, 2015). It would be of interest to design an agroforestry system applicable to the culture of the Asháninka, and to test its performance against their traditional practices.

There are still extensive areas of natural vegetation around Pankirentsy, sufficient to provide hunting and fishing in abundance. While the soil is probably being overexploited in some areas, the plentiful quantity of food currently available to the villagers means that they do not perceive this as a 
problem. A more detailed study on the cycling of nutrients, through evaluations of fluxes and magnitudes, is required to assess the sustainability of the traditional systems employed by the Asháninka Amerindians. Contrary to most expectations, Lawrence et al. (2007) found higher stocks of nutrients and better soil physical characteristics for soil under traditional cultivation than in virgin soil from beneath native forest. Whether this observation is true for Peruvian Amazonia merits investigation.

Vinceti et al. (2013) have pointed out some of the constraints that impair the recognition of the role of forests and trees in providing a sustainable diet to humans and thus the implementation of appropriate policies at a national level: 1. knowledge gaps, 2. land tenure and access, 3. extraction and forest deterioration, and 4 . changes in social and cultural contexts. These authors. call for research on all these topics. As forest loss and degradation continue, so the international problem of food security is made worse, by both the concomitant reduction in access to fruits and other forest/ tree products, and ecological alterations which have direct impacts on crop and livestock production (NOORDWIJK et al., 2014).

Van Vliet and co-authors (2012) have projected that shifting cultivation will remain as a component of a diversified landscape, and argue for its importance in improving the welfare of many people. It is important to highlight another reason for recognizing the importance of these traditional land-use systems: they are an expression of culture, through which human beings and indigenous peoples in particular are tied to nature. Changes in agricultural practices, hunting, and other expressions of the relationship between humans and their environment will invariably be reflected in the loss of culture and traditional knowledge. So it is reiterated the need for extensive research into traditional land-use in order to determine the constraints under which such systems can operate sustainably and to search for improvements linked to economics and welfare. Vira et al. (2015) have highlighted the importance of understanding the forest-food relationship in a multifunctional landscape. It is argued that nature is the stage on which we, as humans, must perform and stablish relationships.

\section{CONCLUSIONS}

The traditional slash-and-burn agricultural system in used is based on small plots with areas of up to 2 ha. Asháninka Amerindians prefer to utilize areas of secondary forest in a ten-year cycle pattern - five years of production followed by five years of fallow. The smaller trees' diameter makes it easier to clear and prepare the area for crops. The fallow period within the cycle is short. This is concerning for the sustainability of the system: it corresponds to one third of the recommended minimum fallow period, 
so there is a high risk of soil impoverishment in the cultivated plots as the number of cycles increases. It is important that future work addresses the cycling of nutrients.

There are opportunities for improving traditional agricultural techniques, so that the food security and well-being of indigenous populations can be guaranteed. However, attempts to introduce exotic systems of cultivation should be avoided, as they will force the indigenous families to become dependent on external supplies, placing the preservation of their culture at risk. Any research aimed at developing an agricultural system for an indigenous community needs to consider not only the potential gains in productivity and sustainability, but also the impacts of its insertion on the local cultural traditions.

There is a need to expand studies on traditional agriculture in order to better understand them and to develop new alternatives for use and protection of the Amazon. The cultural and agricultural practices of the indigenous Amerindians of the Amazon are a vast field of study, whose exploration will delve into social and environmental issues.

\section{ACKNOWLEDGMENTS}

To the Asháninka people of the village of Pankirentsy, who willingly opened their doors and provided the data for this study and to the Regional Office of AIDESEP (Association Interétnica de Desarrollo de la Selva Peruana) in Ucayali - ORAU.

\section{REFERENCES}

ACRE, 2010. Secretaria de Estado de Meio Ambiente do Acre. Revista Povos Indígenas no Acre. Rio Branco: Biblioteca da Floresta - Fundação de Cultura e Comunicação Elias Mansour. Acre - Brazil AMELIBIA, L.B. 2013. Los sistemas agrícolas indígenas del Amazonas: una alternativa agroecológica. Interethnic@-Revista de estudos em relações interétnicas. Brasília, Brazil. v. 3, n. 1, p. 1-7. ANDREAE, B. 1980. The economics of tropical agriculture. Farnham Royal, Slough. U.K.: Commonwealth Agricultural Bureaux.

ATTIWILL, P.M. 1994. The disturbance of forest ecosystems: the ecological basis for conservative management. Forest Ecology and Management. USA. v. 63, n. 2-3, p. 247-300.

BENIEST, J., FRANZEL, S., PLACE, F. 1993. Diagnosis \& Design - training exercise book: for Embu - Kenya. Nairobi. ICRAF.

BRADY, N.C. 1996. Alternatives to slash-and-burn: a global imperative. Agriculture, Ecosystems and Environment. Netherlands. v. 58, n. 1, p. 3-11.

CAIRNS, M.F. 2015. Shifting cultivation and environmental change: indigenous people, agriculture and forest conservation. Routledge/Earthscan/Taylor and Francis, Oxford.

CHAO, S. 2012. Forest Peoples: numbers across the world. Forest Peoples Programme, Ed. MoretonOn-Marsh. United Kingdom.

CORNEJO ARANA, C., MATEO, S. 2006. Estrategia regional de la diversidad biológica de Ucayali. Punto Focal Regional de Ucayali. IIAP. Lima, Perú. 
CONKLIN, H.C. 1957. Hanunoo agriculture: a report on an integral system of shifting cultivation in the Philippines. Rome: FAO Forestry Development. (FAO Forestry Development Paper 12).

FAO. 2011. Forest for improved food security and nutrition report. Rome: FAO. Available at: <http://www.fao.org/docrep/014/i2011e/i2011e00.pdf>. Accessed on Feb. 8 ${ }^{\text {th }}, 2017$.

FUNAI - Fundação Nacional do Índio. 2013. Quem São? Available at: <http://www.funai.gov.br/index.php/indios-no-brasil/quem-sao?limitstart=0\#>. Accessed on October $24^{\text {th }}, 2013$.

GAZELL, A.C.F., RIGHI, C.A. STAPE, J.L., CAMPOE, O.C. 2012. Tree species richness, does it play a key role on a forest restoration plantation? Bosque. Chile. v. 33, n. 3, p. 245-248.

HARRIS, D.R. 1972. The origins of agriculture in the tropics. American Scientist. USA. v. 60, n. 2 , p.180-193.

ICAA, 2015 - Iniciativa para la Conservación en la Amazonía Andina. Perú Amazonico, Lima. Available at: < https://amazoniaandina.wordpress.com> Accessed on Jun. 20 2015.

INEI - Instituto Nacional de Estadística e Informática. 2015. Perú: sínteses estadísticas. INEI. Peru. Available at: <https://www.inei.gob.pe/media/MenuRecursivo/publicaciones_digitales/Est/Lib1292/libro.pdf>. Accessed on Feb. $21^{\text {st }}, 2017$.

INRENA - Instituto Nacional de Recursos Naturales. 2005. Parque Nacional Alto Purus: Plan Maestro 2005 - 2010. Lima: INRENA.

IVERSEN, J. 1956. Forest Clearance in the Stone Age. Scientific American. USA. v. 194, n. 3, p. 3641.

KITAKA, M.M. 1991. Etnografia Preliminar dos Ashaninka da Amazônia brasileira. p. 162-170 Master's Thesis in Anthropology - State University of Campinas. Campinas - Brazil

LANLY, J.P. 1982. Tropical Forest Resources. Rome: FAO. (FAO Forestry Paper, 30).

LAWRENCE D., ASTIANI D. SYAZHAMAN-KARWUR M., FIORENTINOI I. 2007. Alternative fallow management under shifting cultivation: does tree diversity affect soil fertility? In: Voices from the forest: integrating indigenous knowledge into sustainable upland farming, Ed. M.F. Cairns. Resources for the future. Washington, D.C. Chapter 42. pp. 509-521.

MAYOR A.P., BODMER R.E. 2009. Pueblos Indígenas de la Amazonía Peruana. Iquito: Centro de Estudios Teológicos de la Amazonía.

MUKUL S.A., HERBOHN J., FIRN J. 2016. Tropical secondary forests regenerating after shifting cultivation in the Philippines uplands are important carbon sinks. Scientific Reports 6. USA. n. 22483 DOI: 10.1038/srep22483.

NEWTON, P., MILLER D.C., BYENKYA, M.A.A., AGRAWAL A. 2016. Who are forest-dependent people? A taxonomy to aid livelihood and land use decision-making in forested regions. Land Use Policy. Netherlands v. 57, p. 388-395.

NOORDWIJK M., BIZARD V., WANGPAKAPATTANAWONG P., TATA H.L., VILLAMOR G.B., LEIMONA B. 2014. Tree cover transitions and food security in Southeast Asia. Global Food Security. v. 3, n. 3-4, p. 200-208.

NYE P.H., GREENLAND D.J. 1960, The soil under shifting cultivation. Harpenden, UK: Commonwealth Bureau of Soils. (Technical communications, 51).

PADOCH C., CHOTA INUMA J., DE JONG W., UNRUH J. 1985. Amazonian agroforestry: a marketoriented system in Peru. Agroforestry Systems. Netherlands. v. 3, n. 1, p. 47-58.

PEDROSO Jr. N.N., MURRIETA R.S.S., ADANS C. 2008. A agricultura de corte e queima: um sistema em transformação. Boletim do Museu do Pará Emílio Goeldi. Belém. v. 3, n. 2, p. 153-174. 
PERONI N., MARTINS P.S. 1999. Biodiversidade e Dinâmica evolutiva de espécies cultivadas em roças de agricultura tradicional em áreas de Mata Atlântica. Scientia Agricola. Piracicaba - Brazil. v. 56, n. 3, p. 587-595.

PITMAN R., PITMAn N., ALVAREZ P. 2013. Alto Purus: Biodiversidad, conservación y manejo. Lima: Center for Tropical Conservation.

RIGHI C.A. 2015. Sistemas Agroflorestais: definição e perspectivas. In: Cadernos da Disciplina de Sistemas Agroflorestais, Ed. Righi, C.A. and M.S. Bernardes. ESALQ. Piracicaba - Brazil. Chapter 1. pp. 1-6. (Série Difusão, 1).

SORIA C.M., CASANTO S.E. 2002. Arte y cultura del monte: Asháninka del Perené. Lima: Universidad Nacional Mayor de San Marcos.

VAN VLIET N., MERTZ O., HEINIMANN A., LANGANKE T., PASCUAL U., SCHMOOK B., ADAMS C., SCHMIDT-VOGT D., MESSERLI P., LEISZ S., CASTELLA J.C., JøRGENSEN L., BIRCH-THOMSEN T., HETT C., BECH-BRUUN T., ICKOWITZ A., VU K.C., YASUYUKI K., FOX J., PADOCH C., DRESSLER W., ZIEGLER A.D. 2012. Trends, drivers and impacts of changes in swidden cultivation in tropical forest-agriculture frontiers: a global assessment. Global Environmental Change. Netherlands. v. 22, p.418-429.

VINCETI B., ICKOWITZ A., POWELL B., KEHLENBECK K., TERMOTE C., COGILL B., HUNTER D. 2013. The contributions of forest foods to sustainable diets. Unasylva. Rome. v. 64, n. 241, p. 5464.

VIRA, B., WILDBURGER C., MANSOURIAN S. 2015. Forests, trees and landscapes for food security and nutrition: a global assessment report. Vienna. IUFRO. 172 p. (World Series, 33).

WHITE, D., VELARDE S.J., ALEGRE J.C., TOMICH T.P. 2005. Alternatives to Slash-and-Burn (ASB) in Peru: Summary Report and Synthesis of Phase II. Nairobi, Kenya: Alternatives to Slashand-Burn Programme. 152 p. Available at: <http://www.asb.cgiar.org/PDFwebdocs/White_et_al_2005_ASB-Peru.pdf $>$. Accessed on October $2^{\text {nd }}, 2015$.

ZEE-OT Zonificación Ecológica Económica-Ordenamiento Territorial. 2005. Gobierno Regional de Ucayali. Peru. Available at: <http://siar.regionucayali.gob.pe/tematica/zonificacion-ecologicaeconomica-zee> Accessed on September 10 $0^{\text {th }}, 2015$. 